\title{
Effect of Intraarticular Bupivacaine Administration on Postoperative Pain Relief after Arthrotomic or Arthroscopic Management of Cranial Cruciate Ligament Rupture in Dogs
}

\author{
P. RAUŠER, M. DVOŘÁK, A. NEČAS, L. LEXMAULOVÁ, R. NOVOTNÁ
}

Department of Surgery and Orthopedics, Small Animal Clinic, University of Veterinary and Pharmaceutical Sciences, Brno, Czech Republic

Received November 11, 2004

Accepted November 10, 2005

\begin{abstract}
Raušer P., M. Dvořák, A. Nečas, L. Lexmaulová, R. Novotná: Effect of Intraarticular Bupivacaine Administration on Postoperative Pain Relief after Arthrotomic or Arthroscopic Management of Cranial Cruciate Ligament Rupture in Dogs. Acta Vet Brno 2005, 74: 613-619.

The goal of the study was to disclose superiority of either arthroscopy or arthrotomy in the treatment of CCL rupture with respect to post-surgical pain, to find whether bupivacaine administered intraarticularly is of any value in reducing postoperative pain, and through the present pain scoring system consisting of degree of the lameness, CPS and VAS to recommend therapeutical plan of CCL repair offering the better analgesia.

Thirty-seven dogs with cranial crucial ligament (CCL) rupture were randomly assigned to arthrotomy (20 dogs) or arthroscopy (17 dogs). The dogs were subjected to the intraarticular administration of bupivacaine $2.5 \mathrm{mg} / \mathrm{kg}$ or saline $0.5 \mathrm{ml} / \mathrm{kg}$ (control group) after the closure of joint capsule, the two protocols being distributed at random. Postoperative analgesia was assessed with regard to the degree of the lameness, cumulative pain score (CPS) and visual analogue scale (VAS), recorded at 1, 2, 3, 4, 5, 6, 8, 12 and 24 hours after intraarticular administration of bupivacaine or saline. Postoperative analgesia was most of the time significantly $(p<0.01)$ better in dogs that underwent arthroscopy and received bupivacaine intraarticularly when compared to the other groups. There was no significant difference in postoperative analgesia between arthroscopic control group and arthrotomy groups, both with and without bupivacaine. The results of this study suggest that intraarticular administration of bupivacaine after arthroscopic surgical management of cranial crucial ligament rupture provides satisfactory postoperative analgesia 24 hours after the arthroscopy.
\end{abstract}

Analgesia, knee joint

Cranial cruciate ligament (CCL) rupture is an orthopedic problem, in dogs observed and dealt with quite frequently (Nečas and Zatloukal 2002). The therapy is based on orthopaedic surgery, either arthrotomy or arthroscopy (Laffarque et al. 1999; Nečas et al. 2002; Hoelzler et al. 2004). Whichever method used, it is associated with significant postoperative pain, most often treated with opioids or non-steroidal antiinflammatory drugs (NSAIDs). However, systemic drugs have many unwanted side-effects (Evans 1992). Local anaesthetics are used to provide intraoperative analgesia in order to reduce the amount of general anaesthetics as well as they are employed to control postoperative pain. Local anaesthetics enable the reduction of other analgesic drugs thus reducing their unwanted side-effects. Beside epidural analgesia (Pascoe 1992) and femoral block analgesia (Dauri et al. 2003), the topical intraarticular administration is preferred for its simplicity and minimizing of side-effects, as well as other systemic effects (S a mmarco et al. 1996).

Bupivacaine is an amide local anaesthetic that causes blockade of nociceptive input (Strichartz and Covino 1990). The onset is delayed (5 to 10 min to observing first signs

Address for correspondence:

MVDr. Petr Raušer Ph.D.

Department of Surgery and Orthopedics, Small Animal Clinic

University of Veterinary and Pharmaceutical Sciences

Palackého 1/3, 61242 Brno, Czech Republic

Phone: +420 541562362

E-mail: rauserp@vfu.cz

http://www.vfu.cz/acta-vet/actavet.htm 
of pain relief). Analgesia lasts for 4-6 h (Lascelles 2000), even up to $24 \mathrm{~h}$ after intraarticular injection (Heard et al. 1992).

Clinical trials held on humans did not reveal any difference in pain perception in individuals treated with intraarticular bupivacaine as compared with control group (saline) (Kirkeby and Aase 1987; Raja et al. 1992; Khoury et al. 1992; Heard et al. 1992; Dickstein et al. 1991). Sammarco et al. (1996) compared postoperative pain management with intraarticular bupivacaine, morphine, or saline in dogs after arthrotomy of the knee joint for the treatment of CCL rupture. The authors observed marked superiority of intraarticular bupivacaine over morphine.

Bubenik et al. (2002) compared arthrotomy to arthroscopy with regard to the presence of postoperative pain, expressed as lameness, in dogs. No significant differences between groups were observed. However, arthroscopy when compared to arthrotomy is considered to be gentler, less invasive and facilitating fast recovery and lower post-surgical morbidity in dogs according to Hoelzler et al. (2004). Lower postoperative pain was also observed in humans (Laffargue et al. 1999).

There are no data on the effect of intraarticular bupivacaine administration on postoperative pain relief after either arthroscopic or arthrotomic repair of CCL rupture in the literature available. Thus, our goal was to evaluate post surgical welfare of dogs following each procedure with or without bupivacaine given intraarticularly.

\section{Materials and Methods}

Animals

Thirty-seven dogs (20 males and 17 females) weighing $32 \pm 13.76 \mathrm{~kg}$ were included in the study, with the average of $6.5 \pm 4.41$ years of age. CCL rupture was diagnosed with physical and radiological examination. All the dogs were categorized as ASA (American Society of Anesthesiology) class I or class II based on preanaesthetic examination. The dogs were without any analgetic medication. Dogs were randomized (alternated) into two main groups, At and As, and each group into the two subgroups. Dogs from At group underwent arthrotomic repair of the CCL rupture, while in dogs from As group arthroscopy was performed. Dogs in subgroups were given either bupivacaine - AtB $(n=10)$ and $\operatorname{AsB}(n=8)$, or saline as a control - AtS $(n=10)$ and $A s S(n=9)$ for postoperative analgesia.

Protocol of the experiment

General preanesthetic examination including heart rate (HR), respiratory rate (RR) and rectal temperature (T) was performed in all dogs, followed by orthopaedic examination. Only patients with unilateral rupture of CCL were included in study protocol.

Intravenous catheter was inserted and the dogs were premedicated with medetomidine $(0.02 \mathrm{mg} / \mathrm{kg}$; Domitor, Pfizer) and butorphanol $(0.2 \mathrm{mg} / \mathrm{kg}$; Butomidor, Richter) intravenously. Anaesthesia was maintained by a mixture of oxygen, nitrous oxide $(1: 1)$ and halothane (Narcotan, Léčiva) using a semi-closed re-breathing system, after induction by propofol (Propofol, Abbott) injected to effect. Heart rate, respiratory rate, non-invasive blood pressure, end-tidal partial pressure of carbon dioxide and saturation of haemoglobin by oxygen was monitored. Medetomidine was antagonized with atipamezol $(0.04 \mathrm{mg} / \mathrm{kg}$ intramuscularly; Antisedan, Pfizer $)$ postoperatively.

Two surgical procedures were utilized for CCL repair, arthrotomy and arthroscopy, both of them lege artis (Vasseur 2003). All surgeries were performed by the same experienced surgeon. Following suture of the joint capsule, before closing of subcutaneous tissue, either $0.5 \%$ bupivacaine hydrochloride (Marcaine, Astra Zeneca) at a dose of $2.5 \mathrm{mg} / \mathrm{kg}$ (dogs from groups AtB and AsB), or sterile saline at a dose of $0.5 \mathrm{ml} / \mathrm{kg}$ (dogs from groups $\mathrm{AtS}$ and $\mathrm{AsS}$ ) was injected into the joint through the $22 \mathrm{G}$ needle.

The level of postoperative pain was established by cumulative pain score (CPS), visual analogue scale (VAS) (Hardie 2000) and the degree of lameness (Sumner-Smith 1996). The CPS was based on observation/measurement. The CPS values were set in the range between 0 and $28(0=$ no pain, $28=$ severe pain $)$, while VAS values were set between 0 and $10(0=$ no pain, $10=$ the worst pain possible $)$. We recognized 5 degrees of lameness: $0=$ no lameness, $1=$ mild lameness at a slow trot, none while walking, $2=$ mild lameness while walking, obvious at trot, $3=$ obvious lameness at both walk and trot, $4=$ unable to put the foot on the ground.

All 3 parameters were recorded before surgery and 1,2, 3, 4, 5, 6, 8, 12 and 24 hours after intraarticular injection of either bupivacaine or saline. The study was set as double blind, and pain assessment was always performed by the same person. The evaluation of CPS and VAS was performed prior degree of the lameness was established at walk and trot. Patients given other analgesics than stated in anaesthetic protocol were excluded from the study.

Endpoints

The goal of the study was (a) to disclose superiority of either arthroscopy or arthrotomy in the treatment of CCL 
rupture with respect to post-surgical pain; (b) to find out whether bupivacaine administered intraarticularly is of any value in reducing postoperative pain; and (c) through the pre-set pain scoring system consisting of degree of the lameness, CPS and VAS to recommend therapeutical plan of CCL repair offering the better analgesia.

\section{Statistical analyses}

The data summarizing heart rate, respiratory rate and body temperature were compared between groups at all time points. Non-parametric multiple comparisons tests (Kruskal-Wallis test, Steel-Dwass test, Jonkheere test) were used for data analysis. $P$ value was set at 0.05 for significance and 0.01 for high significance.

\section{Results}

There was no significant difference between groups with respect to age, weight and sex. Preoperative values for HR, RR, T, degree of lameness, CPS and VAS were not significantly different between groups.

One hour after bupivacaine or saline administration, only 3 dogs were awake enough to be able to undergo examination. Because of that, we omitted 1 hour checkout from the results.

Table 1. Degree of lameness

\begin{tabular}{|l|c|c|c|c|c|c|c|c|c|c|}
\hline & \multicolumn{10}{|c|}{ Time (h) after administration } \\
\cline { 2 - 11 } & Before & $\mathbf{1}$ & $\mathbf{2}$ & $\mathbf{3}$ & $\mathbf{4}$ & $\mathbf{5}$ & $\mathbf{6}$ & $\mathbf{8}$ & $\mathbf{1 2}$ & $\mathbf{2 4}$ \\
\hline AtB & $1.4 \pm 0.70$ & & $3.7 \pm 0.52$ & $3.8 \pm 0.42$ & $3.8 \pm 0.42$ & $3.6 \pm 0.52$ & $3.6 \pm 0.52$ & $3.8 \pm 0.42$ & $3.8 \pm 0.42$ & $4.0 \pm 0.00$ \\
\hline AtS & $1.2 \pm 0.42$ & & $3.7 \pm 0.48$ & $3.6 \pm 0.53$ & $3.6 \pm 0.53$ & $3.6 \pm 0.53$ & $4.0 \pm 0.82$ & $4.0 \pm 0.82$ & $3.5 \pm 0.58$ & $3.0 \pm 0.82$ \\
\hline AsB & $0.9 \pm 0.32$ & & $2.0 \pm 0.53$ & $2.0 \pm 0.67$ & $3.0 \pm 0.67$ & $3.0 \pm 0.47$ & $3.0 \pm 0.71$ & $4.0 \pm 0.00$ & $3.0 \pm 0.53$ & $2.0 \pm 0.71$ \\
\hline AsS & $1.2 \pm 0.42$ & & $3.7 \pm 0.48$ & $3.4 \pm 0.97$ & $3.1 \pm 1.45$ & $2.7 \pm 1.25$ & $3.4 \pm 0.53$ & $3.4 \pm 0.53$ & $3.4 \pm 0.53$ & $2.9 \pm 1.07$ \\
\hline
\end{tabular}

Fig. 1. Degree of lameness

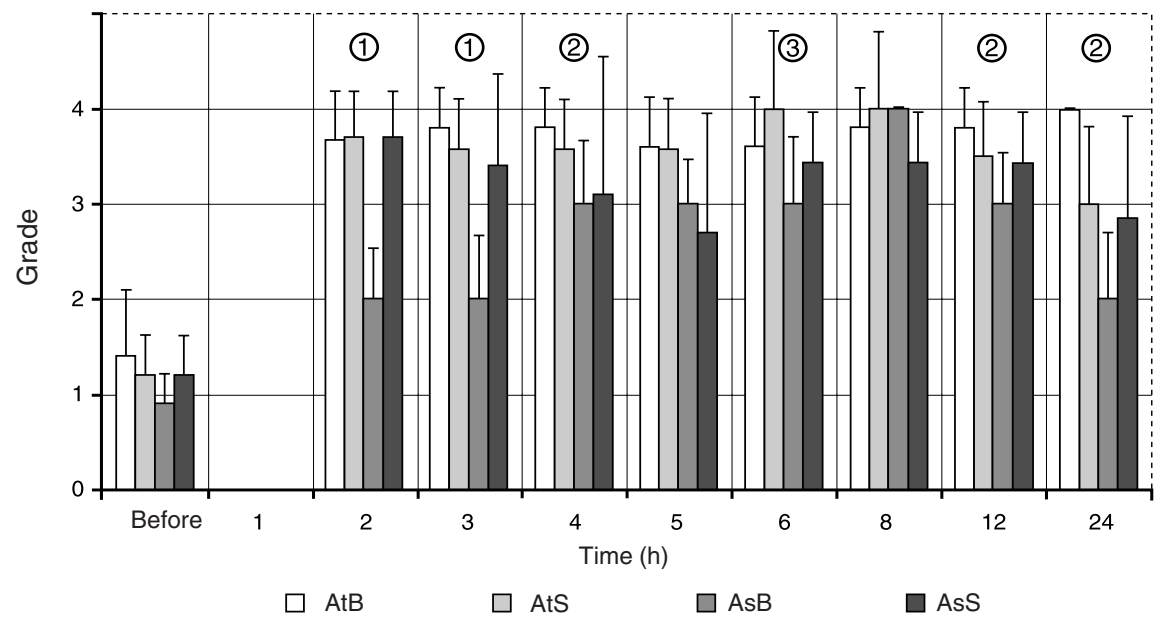

(1) shows the difference $(p<0.01)$ between group AsB and groups AtB, AtS, AsS; (2) show the difference $(p<0.01)$ between group AsB and group AtB; (3) show the difference $(p<0.05)$ between group AsB and groups AtB, AtS

As it can be seen from Table 1 and Graph 1 (Degree of the lameness), the AsB group revealed in the average significantly lower degree of the lameness when compared to other groups. Table 2 and Graph 2 (Cumulative pain score) reveals most of the time significantly lower pain in AsB group when compared to other groups, too. Statistically significant differences between groups can be seen at 3, 8 and 24 hours after injection only - with AsB patients generally suffering lower pain comparing to the others (see Table 3 and Graph 3 Visual analog scale). 
Table 2. Cumulative pain score (CPS)

\begin{tabular}{|c|c|c|c|c|c|c|c|c|c|c|}
\hline & \multicolumn{10}{|c|}{ Time (h) after administration } \\
\cline { 2 - 11 } & Before & $\mathbf{1}$ & $\mathbf{2}$ & $\mathbf{3}$ & $\mathbf{4}$ & $\mathbf{5}$ & $\mathbf{6}$ & $\mathbf{8}$ & $\mathbf{1 2}$ & $\mathbf{2 4}$ \\
\hline AtB & $0.6 \pm 0.84$ & & $3.0 \pm 1.15$ & $3.2 \pm 0.79$ & $3.4 \pm 1.07$ & $4.0 \pm 3.20$ & $4.4 \pm 4.03$ & $2.0 \pm 0.67$ & $2.0 \pm 0.76$ & $2.8 \pm 2.78$ \\
\hline AtS & $0.6 \pm 0.97$ & & $3.8 \pm 1.32$ & $3.2 \pm 1.55$ & $3.7 \pm 1.60$ & $6.3 \pm 1.60$ & $3.9 \pm 0.90$ & $4.0 \pm 0.82$ & $3.5 \pm 0.58$ & $3.0 \pm 0.82$ \\
\hline AsB & $0.8 \pm 0.92$ & & $1.0 \pm 0.53$ & $0.7 \pm 0.82$ & $4.0 \pm 0.67$ & $4.0 \pm 0.47$ & $2.0 \pm 0.50$ & $2.0 \pm 1.00$ & $1.0 \pm 0.53$ & $0.5 \pm 0.55$ \\
\hline AsS & $0.7 \pm 0.95$ & & $4.4 \pm 1.71$ & $5.0 \pm 0.82$ & $4.4 \pm 0.52$ & $4.0 \pm 0.47$ & $3.4 \pm 0.53$ & $4.3 \pm 1.60$ & $2.9 \pm 1.07$ & $3.7 \pm 2.14$ \\
\hline
\end{tabular}

Fig. 2. Cumulative pain score (CPS)

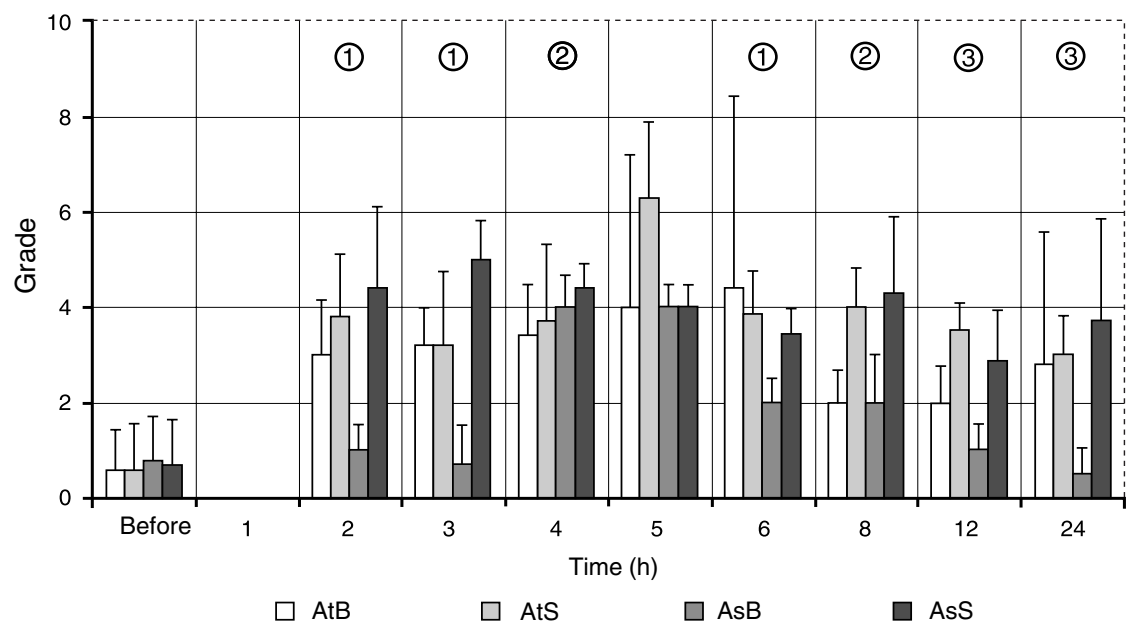

(1) show the difference $(p<0.01)$ between group AsB and groups AtB, AtS, AsS; (2) show the difference $(p<0.01)$ between group AsB and groups AtS, AsS; (3) show the difference $(p<0.05)$ between group AsB and groups AtB, AtS, AsS

Table 3. Visual analogue scale (VAS)

\begin{tabular}{|l|c|c|c|c|c|c|c|c|c|c|}
\hline & \multicolumn{10}{|c|}{ Time (h) after administration } \\
\cline { 2 - 11 } & Before & $\mathbf{1}$ & $\mathbf{2}$ & $\mathbf{3}$ & $\mathbf{4}$ & $\mathbf{5}$ & $\mathbf{6}$ & $\mathbf{8}$ & $\mathbf{1 2}$ & $\mathbf{2 4}$ \\
\hline AtB & $0.5 \pm 0.71$ & & $3.3 \pm 0.50$ & $5.6 \pm 2.27$ & $5.8 \pm 2.04$ & $5.6 \pm 1.84$ & $5.2 \pm 1.40$ & $5.3 \pm 0.82$ & $5.2 \pm 1.55$ & $5.2 \pm 1.23$ \\
\hline AtS & $0.9 \pm 1.10$ & & $4.9 \pm 1.20$ & $4.7 \pm 1.42$ & $4.6 \pm 1.72$ & $4.6 \pm 1.72$ & $4.0 \pm 1.15$ & $3.0 \pm 1.15$ & $3.0 \pm 1.15$ & $3.0 \pm 1.15$ \\
\hline AsB & $0.8 \pm 1.03$ & & $3.0 \pm 0.53$ & $3.0 \pm 0.94$ & $5.0 \pm 0.47$ & $5.0 \pm 0.67$ & $5.0 \pm 1.00$ & $6.0 \pm 0.50$ & $4.0 \pm 0.53$ & $2.0 \pm 0.58$ \\
\hline AsS & $0.9 \pm 0.99$ & & $5.1 \pm 1.45$ & $5.1 \pm 1.45$ & $4.5 \pm 1.78$ & $4.1 \pm 1.45$ & $4.0 \pm 0.82$ & $4.0 \pm 0.58$ & $3.4 \pm 0.53$ & $3.4 \pm 0.53$ \\
\hline
\end{tabular}

\section{Discussion}

Pain is the phenomenon following every surgery, affecting not only welfare of the patient but the healing process as well. Good quality analgesia has not been often part of current practice until recently (Crane 1987). Achievement of joint pain relief by intraarticular administration of local anaesthetics became very popular in human medicine, especially useful following less invasive procedures such as arthroscopy (Boden et al. 1994). Intraarticular administration of bupivacaine at the end of arthroscopy enhances postoperative analgesia in humans significantly (Dickste in et al. 1991; Heard et al. 1992; Khoury et al. 1992; Raja et al. 1992), the data supporting our hypothesis and in agreement with our results. Laffargue et al. (1999) reported better analgesia during early postoperative period $(<12 \mathrm{~h})$ in humans. Our data suggest that in the CCL rupture repair in 
Fig. 3. Visual analogue scale (VAS)

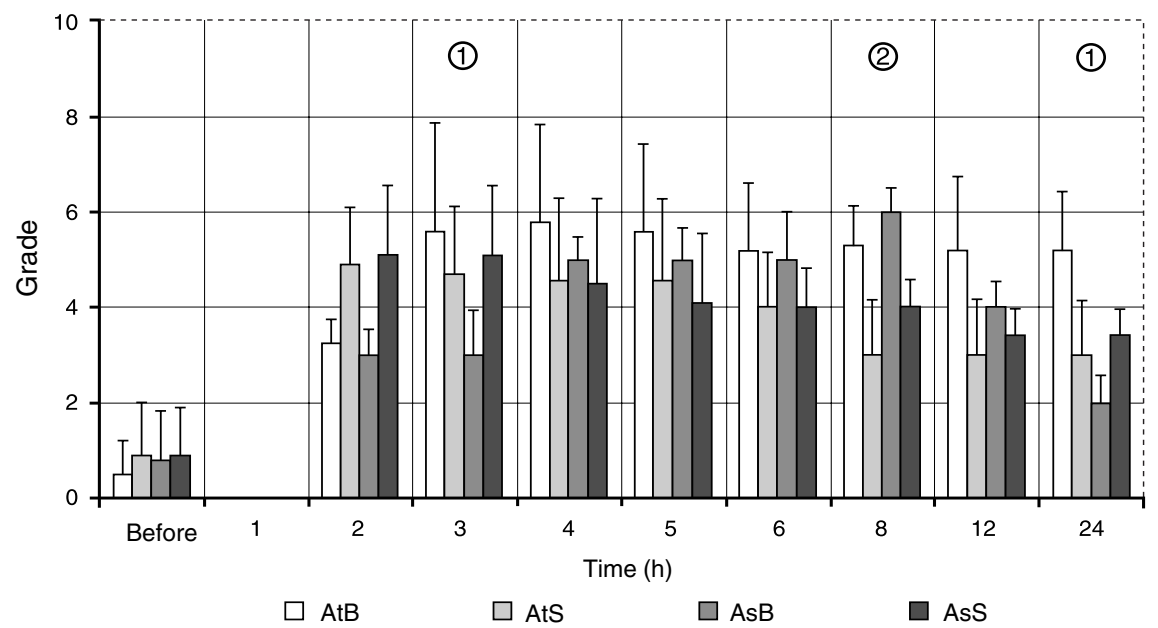

(1) show the difference $(p<0.01)$ between group AsB and group AtS; (2) show the difference $(p<0.01)$ between group AsB and groups AtB, AsS

dogs, no significant difference in the quality of analgesia between early $(<12 \mathrm{~h})$ and late $(>12 \mathrm{~h})$ period was observed. Our data of AsB group are in agreement with Osborne and Keene (1993) and A te s et al. (1994), since these authors also did not find time dependence regarding the quality of postoperative analgesia.

In our study, highly significant differences were discovered $(p<0.01)$ between groups, which can be due to rather small population of dogs included into groups. The best analgesia evaluated according to the degree of lameness was observed in patients undergoing arthroscopy and treated with bupivacaine intraarticularly. Most of the time the difference was significant when the data were compared with other treatment groups. However, we did not find improvement in terms of postoperative analgesia when bupivacaine was given to patients after arthrotomy comparing to the arthrotomy control group. The data are contradictory to S a m marco et al. (1996), who reported that intraarticular bupivacaine does improve postoperative analgesia after arthrotomy. This contradiction may be due to different criteria of pain assessment in the protocols used. Our pain evaluation was based on the degree of lameness, CPS and VAS, while Sammarco et al. (1996) omitted the degree of lameness, adding changes in applied force as another major endpoint, in which pain can be expressed more notably.

According to Heard et al. (1992) analgesia should last up to $24 \mathrm{~h}$ after bupivacaine given intraarticularly, the statement supporting our data. However, some other authors (Khoury 1992; Raja 1992) reported quite different data, showing pain relief a bit shorter, lasting few hours only, corresponding the pharmacokinetics of the local anaesthetic more precisely (Strichartz and Covino 1990; Lascelles 2000).

Bupivacaine hydrochloride at the dose of $2.5 \mathrm{mg} / \mathrm{kg}$ has its plasma peak level far bellow direct myocardial toxicity (Liu et al. 1982), so therapeutical doses are safe enough to be useful for wide range of patients.

As suggested by Sammarco et al. (1996), who measured also blood pressure as a vital function indicator, we did not find any systemic response to bupivacaine given intraarticularly. 
Some authors were trying to point out detrimental effect of bupivacaine on joint cartilage, mainly through the inhibition of synthesis of proteoglycans. However, the same changes can be observed after administration of saline while they often resolve after 3 days without ultrastructural damage of chondrocytes (Nole et al. 1985). That is why we do not consider bupivacaine as potentially harmful to cartilage.

Whenever the effect of intraarticular bupivacaine is compared with opioids, bupivacaine is considered as more potent (Sammarco et al. 1996); moreover, opioids require the presence of inflammation within the joint to penetrate the membranes (Keates et al. 1999), condition which does not apply to bupivacaine. Some authors prefer epidural analgesia and femoral block over intraarticular analgesia (Dauri et al. 2003); although some others did not find significant difference (Goransson et al. 1997). Availability and simple technique of intraarticular injection, as well as long lasting analgesia remain advantages of this method (Heard et al. 1992).

When compared the two methods of CCL repair and postoperative analgesic protocol, we recommend arthroscopy as a procedure and intraarticular bupivacaine as analgesic of choice, mainly for long-lasting analgesia, its usefulness in non-inflammatory joints, minimum toxicity for the patient and minimum damage to joint cartilage.

\section{Vliv intraartikulárně podaného bupivakainu na pooperační bolestivost po artrotomickém nebo artroskopickém ošetření ruptury předního zkřiženého vazu u psů}

U 37 zdravých psů rozdělených do 4 skupin bylo provedeno artrotomické nebo artroskopické ošetření ruptury předního zkříženého vazu kolene s nebo bez pooperační intraartikulární aplikace bupivakainu $\mathrm{v}$ dávce $2.5 \mathrm{mg} / \mathrm{kg}$. Pooperačním hodnocením bolestivosti na základě stupně kulhání, kumulativního skóre bolesti (CPS) a vizuální analogické škály (VAS) v čase 1, 2, 3, 4, 5, 6, 8, 12 a 24 h po intraartikulární aplikaci se jeví jako nejméně bolestivá artroskopie s aplikací bupivakainu. Stupeň kulhání, CPS i VAS jsou u této skupiny výrazně nižší $(p<0.01)$ oproti ostatním skupinám včetně kontrolní artroskopické skupiny. Kontrolní artroskopická skupina neprokázala výraznější odchylky oproti skupinám po artrotomii. Pro navození kvalitní dlouhotrvající analgezie při ošetření ruptury předního zkříženého vazu kolene proto doporučujeme jako analgeticky nejlepší řešení artroskopii s aplikací bupivakainu.

\section{Acknowledgement}

This work was supported by grant of the Ministry of Education, Youth and Sports of the Czech Republic (Research Project No. 161700002).

\section{References}

ATES Y, KINIK H, BINNET MS, ATES Y, CANAKCI N, KECIK Y 1994: Comparison of prilocaine and bupivacaine for post-arthroscopy analgesia. Arthroscopy 10: 108-109

BODEN BP, FASSLER S, COOPER S, MARCHETTO PA, MOYER RA 1994: Analgesic effect of intraarticular morphine, bupivacaine, and morphine/bupivacaine after arthroscopic knee surgery. Arthroscopy 10: 104-107

BUBENIK LJ, JOHNSON SA, SMITH MM, HOWARD RD, BROADSTONE RV 2002: Evaluation of lameness associated with arthroscopy of the normal canine cubital joint. Vet Surgery 31: 23-31

CRANE S 1987: Perioperative analgesia: A surgeon s perspective. J Amer Vet Med Assoc 191: 1254-1257

DAURI M, POLZONI M, FABBI E, SIDIROPOULLOU T, SERVETTI S, CONIGLIONE F, MARIANI P, SABATO AF 2003: Comparison of epidural, continuous femoral block and intraarticular analgesia after anterior cruciate ligament reconstruction. Acta Anaesthesiol Scand 47: 20-25

DICKSTEIN R, RAJA SN, JOHNSON C 1991: Comparison of intraarticular bupivacaine and morphine for analgesia following arthroscopic knee surgery. Anesthesiology 75(3A): A767

EVANS AT 1992: Precautions when using opioid agonist analgesics. In: HASKINS SC, KLIDE AM: Opinions of small animal anesthesia. Vet Clin N Amer-Small Anim 22: 362-363

GORANSON BD, LANG S, CASSIDY JD, DUST WN, McKERRELL J 1997: A comparison of three regional anaesthesia techniques for outpatient knee arthroscopy. Can J Anaesth 44: 371-376

GURKAN Y, KILICKAN L, BULUC L, MUEZZINOGLU S, TOKER K 1999: Effects of diclofenac and intraarticular morphine/bupivacaine on postarthroscopic pain control. Minerva Anestesiol 65: 741-745 
HARDIE ME 2000: Recognition of pain behavior in animals. In: HELLEBREKERS LJ: Animal pain. Van der Wees, Utrecht, pp. 51-69.

HEARD SQ, EDWARDS T, FERRARI D, HANNA D, WONG PD, LILAND AWILLOCK MM 1992: Analgesic effects of intraarticular bupivacaine or morphine after arthroscopic knee surgery: A randomized, prospective, double-blind study. Anesth Analg 74: 822-826

HOELZLER MG, MILLIS DL, FRANCIS DA, WEIGEL JP 2004: Results of arthroscopic versus open arthrotomy for surgical management of cranial cruciate ligament deficiency in dogs. Vet Surgery 33: 146-153

KEATES HL, CRAMOND T, SMITH MT 1999: Intraarticular and periarticular opioid binding in inflamed tissue in experimental canine arthritis. Anesth Analg 89: 409-415

KHOURY GF, CHEN ACN, GARLAND DE, STEIN C 1992: Intraarticular morphine, bupivacaine, and morphine/bupivacaine for pain control after knee videoarthroscopy. Anesthesiology 77:263-266

KIRKEBY OJ, AASE S 1987: Knee arthroscopy and arthrotomy under local anesthesia. Acta Orthop Scand 58: $133-134$

LAFFARGUE P, DELALANDE JL, MEILLET M, VANHECKE C, DECOULX J 1999: Reconstruction of the anterior cruciate ligament: arthrotomy versus arthroscopy. Rev Chir Orthop Reparat App 85: 367-373

LASCELLES BDX 2000: Clinical pharmacology of analgesic agents. In: HELLEBREKERS LJ: Animal pain. Van der Wees, Utrecht, pp. 85-116.

LIU P, FELDMAN HS, COVINO BM, GIASI R, COVINO BG 1982: Acute cardiovascular toxicity of intravenous amide local anesthetics in anesthetized ventilated dogs. Anesth Analg 61: 317-322

NEČAS A, SRNEC R, KECOVÁ H 2002: Diagnostic reliability of stifle arthroscopy of pathological changes in cruciate deficient knee. Acta Vet Brno. 71: 249-256

NEČAS A, ZATLOUKAL J 2002: Factors related to the risk of meniscal injury in dogs with cranial cruciate ligament rupture. Acta Vet Brno 71: 77-84

NOLE R, MUNSON NM, FULKERSON JP 1985: Bupivacaine and saline effects on articular cartilage. Arthroscopy 1: 123-127

OSBORNE D, KEENE G 1993: Pain relief after arthroscopic surgery of the knee: A prospective, randomized, and blinded assessment of bupivacaine and bupivacaine with adrenalin. Arthroscopy 9: 177-180

PASCOE PJ 1992: Advantages and guidelines for using epidural drugs for analgesia. Vet Clin N Amer-Small Anim 22: 421-423

RAJA SN, DICKSTEIN RE, JOHNSON CA 1992: Comparison of analgesic effects of intraarticular bupivacaine and morphine following arthroscopic knee surgery. Anesthesiology 77: 1143-1147

SAMMARCO JL, CONZEMIUS MG, PERKOWSKI SZ, WEINSTEIN MJ, GREGOR TP, SMITH GK 1996: Postoperative analgesia for stifle surgery: A comparison of intra-articular bupivacaine, morphine, or saline. Vet Surgery 25: 59-69

SUMNER-SMITH G 1996: Gait analysis and orthopedic examination. In: SLATTER D: Textbook of small animal surgery. 2nd ed., Saunders, Philadelphia, pp. 1577-1586

STRICHARTZ GR, COVINO BG 1990: Local anesthetics. In: MILLER RD: Anesthesia. 3rd ed., Churchill Livingstone, New York, pp. 437-466

VASSEUR PB 2003: Stifle joint. In: SLATTER D: Textbook of small animal surgery. 3rd ed., Saunders, Philadelphia, pp. 2103-2116

ZATLOUKAL J, NEČAS A, DVOŘÁK M 2000: Measuring craniocaudal instability in stifle joints of dog using stress radiographs. Acta Vet Brno. 69: 311-318 
